\section{Effects of cadmium on the glial architecture in lizard brain}

\author{
Rossana Favorito, Antonio Monaco, \\ Maria C. Grimaldi, Ida Ferrandino \\ Department of Biology, University of \\ Naples Federico II, Italy
}

\begin{abstract}
The glial cells are positioned to be the first cells of the brain parenchyma to face molecules crossing the blood-brain barrier with a relevant neuroprotective role from cytotoxic action of heavy metals on the nervous system. Cadmium is a highly toxic metal and its levels in the environment are increasing due to industrial activities. This element can pass the blood-brain barrier and have neurotoxic activity. For this reason we have studied the effects of cadmium on the glial architecture in the lizard Podarcis siculus, a significant bioindicator of chemical exposure due to its persistence in a variety of habitats. The study was performed on two groups of lizards. The first group of $P$. siculus was exposed to an acute treatment by a single i.p. injection ( $2 \mathrm{mg} / \mathrm{kg}-\mathrm{BW})$ of $\mathrm{CdCl}_{2}$ and sacrificed after 2, 7 and 16 days. The second one was used as control. The histology of the brain was studied by Hematoxylin/Eosin and Cresyl/Violet stains while the glial structures were analyzed by immunodetection of the glial fibrillary acidic protein (GFAP), the most widely accepted marker for astroglial cells. Evident morphological alterations of the brain were observed at 7 and 16 days from the injection, when we revealed also a decrease of the GFAP-immunopositive structures in particular in the rhombencephalic ventricle, telencephalon and optic tectum. These results show that in the lizards an acute exposure to cadmium provokes morphological cellular alterations in the brain but also a decrement of the expression of GFAP marker with possible consequent damage of glial cells functions.
\end{abstract}

\section{Introduction}

The central nervous system is built from two broad categories of cells, neurons and glial cells which include the astrocytes, oligodendrocytes, ependymal cells and microglia. For a long time glial cells were considered to have a limited role in support- ing neurons. Now they are recognized as key players in virtually all aspects of brain function in all vertebrates. ${ }^{1-3}$ Cell bodies of astrocytes are juxtaposed between neurons and the capillary endothelium to form the blood-brain barrier (BBB). Given these cytoarchitectural features, they are the first cells of the brain parenchyma to encounter foreign molecules crossing this barrier. ${ }^{4}$ For this they have also a neuroprotective action from cytotoxic action of heavy metals. ${ }^{5}$ Cadmium (Cd) is a heavy metal with a long biological half-life of $\sim 30$ years with a high potential toxicity. Unfortunately this metal is increasingly in the environment as the result of industrial and agricultural practices, ${ }^{6}$ thereby entering the food chain. ${ }^{7}$ It is known that an acute exposure to $\mathrm{Cd}$ produces toxicity to the lungs, testes and brain, while a chronic exposure to this metal determines renal dysfunction, anaemia and osteoporosis. ${ }^{8-11}$ Numerous studies provide evidence that $\mathrm{Cd}$ induces neuronal toxicity and damage to the brain. ${ }^{12,13}$ The brain accumulates metals that are often localized in the astroglia. ${ }^{14}$ In mammals some studies have been carried out on the toxic effect of heavy metals on glia, for this it has been possible to observe that metals like $\mathrm{Cd}, \mathrm{Tl}$, $\mathrm{Zn}$ and $\mathrm{Pb}$ induce morphological changes in the populations of glial cells. ${ }^{15,16}$ Although the complexity of the cellular and biochemical actions of $\mathrm{Cd}$ has been discussed in a number of studies, the underlying mechanisms are not completely understood. It is not clear whether all the different populations of brain cells (i.e., neurons, glial cells, and endothelial cells) are equally sensitive to this metal. The scope of the present study has been to observe the possible morphological changes induced by $\mathrm{CdCl}_{2}$ on the astroglia of the lizard Podarcis siculus. Among vertebrates, the class Reptilia has been relatively understudied in the field of ecotoxicology, although it is considered to be suitable as bioindicator of chemical exposure due to its persistence in a variety of habitats. ${ }^{17-21}$ The present study was performed by a morphological analysis of the brain at light microscope and by immunodetection of the glial fibrillary acidic protein (GFAP) in lizards exposed to an acute intraperitoneal treatment with $\mathrm{CdCl}_{2}$. GFAP is the main component of glial filaments expressed in the astroglial cells and it is accepted as a reliable specific molecular marker for these cells. ${ }^{22}$ GFAP shows a considerable stability in its molecular and antigenic characteristics across vertebrate phylogeny and a clear cross reactivity to the anti-mammalian GFAP also in reptiles. ${ }^{23-27}$
Correspondence: Ida Ferrandino, University of Naples Federico II, Department of Biology, Via Mezzocannone 8, 80134 Naples, Italy. Tel. +39.081.2535046 - Fax: +39.081.2535035. E-mail: ida.ferrandino@unina.it

Key words: Lizard; cadmium; glial cells; glial fibrillary acidic protein; brain; histology; immunohistochemistry.

Contributions: RF, research design, experiments performing, data analysis; AM, immunohistochemistry studies, data analysis, manuscript writing; MCG, data analysis, manuscript writing; IF, research design, data analysis, manuscript writing.

Received for publication: 10 October 2016. Accepted for publication: 22 December 2016.

This work is licensed under a Creative Commons Attribution-NonCommercial 4.0 International License (CC BY-NC 4.0).

CCopyright R. Favorito et al., 2017

Licensee PAGEPress, Italy

European Journal of Histochemistry 2017; 61:2734 doi:10.4081/ejh.2017.2734

\section{Materials and Methods}

\section{Animals}

The study was performed on 30 adult females of Podarcis siculus, captured near Naples (Italy) and kept under controlled conditions of light and temperature with food and water ad libitum. A group of 15 specimens received intraperitoneally (i.p.) a single injection (2 $\mathrm{mg} / \mathrm{kg}-\mathrm{BW})$ of $\mathrm{CdCl}_{2}$ (Sigma-Aldrich, St. Louis, MO, USA). This dose was chosen according to previous reports. ${ }^{18,19,28}$ Another group of 15 specimens was used as control by the i.p. injection of physiological solution. Experiments were performed in accordance with the Guideline for Animal Experimentation of the Italian Department of Health under the supervision of a veterinarian, and organised to minimize stress and the number of lizards used. The animals were sacrificed at 2, 7 and 16 days from treatments. The brains were immediately removed and processed.

\section{Histology and immunohistochemistry}

The brains of control and treated lizards were fixed in Bouin's solution for $48 \mathrm{~h}$ at room temperature and then dehydrated and embedded in paraffin. Serial sections of 6 $\mu \mathrm{m}$ were processed by Hematoxylin/Eosin (H\&E) and Cresyl/Violet stains for the general morphology of the brains and by the 
$\mathrm{ABC}$ immunohistochemistry technique for the revelation of GFAP. The polyclonal antisera anti-GFAP (Dako, Glostrup, Denmark) was used at specific working dilution of $1 / 100$ overnight at $4^{\circ} \mathrm{C}$. Visualization was carried out using the Vectastain Elite ABC kit (Vector Labs, Inc., Burlingame, CA, USA) and revealed by 3 $\mathrm{mg}$ of 3,3'-diaminobenzidine-tetrahydrochloride (Sigma-Aldrich) in $10 \mathrm{~mL}$ PBS and $150 \mu \mathrm{L} 3 \% \mathrm{H}_{2} \mathrm{O}_{2}$. The sections were then counterstained with hematoxylin for 1 min. Antibody specificity was assessed by omitting the primary antisera. The images were examined and acquired by a Kontron Electronic Imaging System KS300 (Zeiss, Oberkochen, Germany).

\section{Quantification of GFAP}

An objective measure of the area containing brown pixels corresponding to immunoreactive staining for GFAP was quantified using the software ImageJ (W.S. National Institutes of Heart, Bethesda MD, USA) as described previously. ${ }^{29,30}$ Images were converted to Grey Scale "RGB stack" and green channel image used for analysis. Total area of immunostained tissue above the threshold was quantified and expressed as proportion of tissue animal total observed area. The test was replicated on serial sections of three animals for each experimental group. The data were summarized by GraphPad Prism 5.

\section{Statistical analysis}

The data of mean percentage values for the different brain areas of lizards of different experimental groups were analysed using the software GraphPad Prism 5 and the significance of differences between experimental groups was assessed by ANOVA followed by Tukey post-hoc test. Significance was taken as $\mathrm{P}<0.05$.

\section{Results}

Control lizards appeared in good health and without signs of any abnormality. None of control or treated lizards died during the course of experiment. However, in the treated lizards we observed irritability, increased aggression and a reduction in the food consumed.

\section{Histology}

The general histology of $P$. siculus brain in control specimens showed a homogeneous tissue with well defined structures in all the areas of the organ. In fact both the neurons and the glial cells showed a regular shape with well defined edges. The nervous tissue was well vascularized and showed a good affinity to stains (Figures 1a and 2a). The ependymocytes showed globular shape and were organized in their epithelial layer lining the ventricular lumen (Figure 1c). No particular alteration was observed in lizard brains at 2 days from treatment. Instead, after 7 and 16 days we observed a decrease of tinctorial affinity of the nervous cells in particular in the area of optic tectum, in the cerebellum (Figure 1b) and in the ependyma (Figure 1d) where the ependymocytes showed a marked cellular
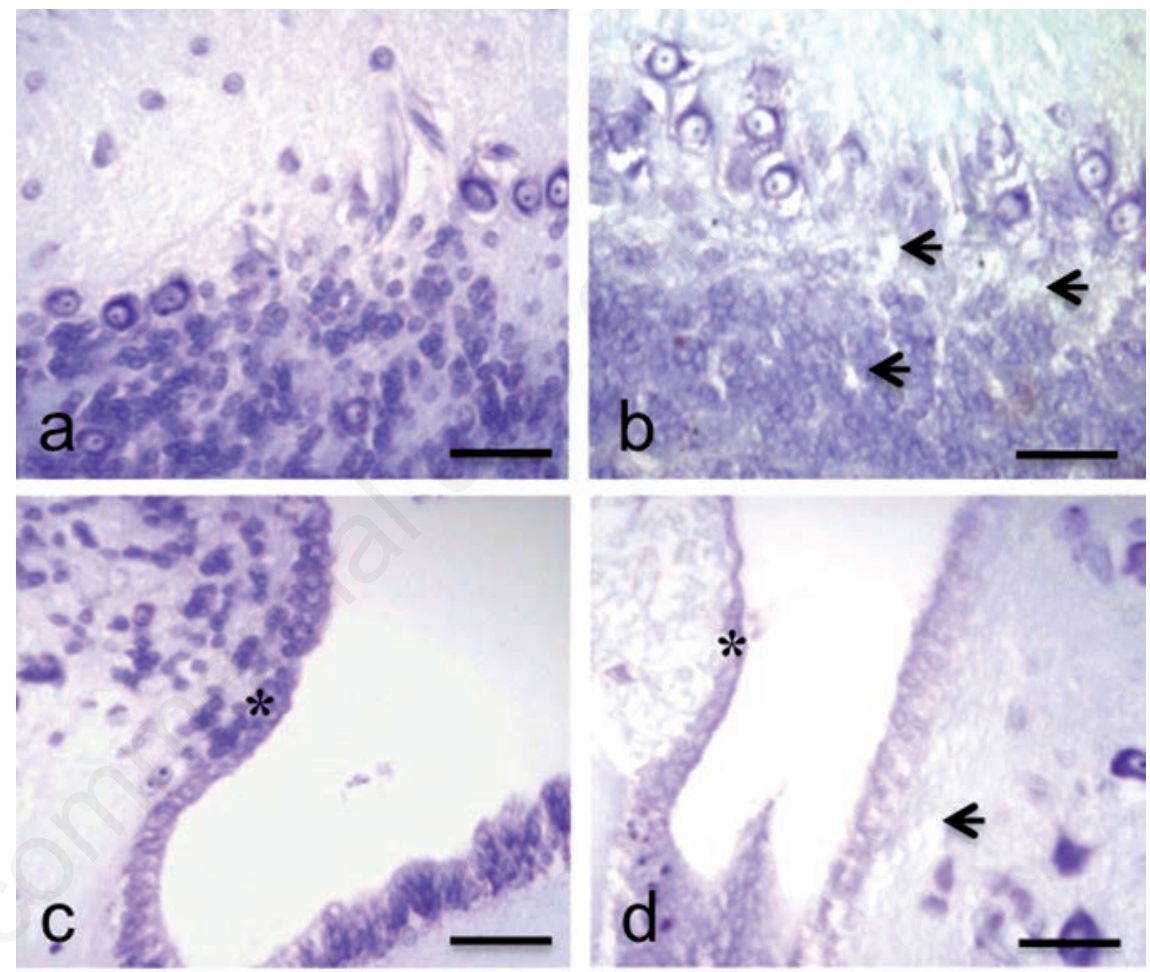

Figure 1. Cresyl-Violet stain. Sections of P. siculus brain. Cerebellum (a) and rhombencephalic ventricle (c) in control lizard: good tissutal conservation and well-defined morphology of the nervous and ependymal (*) cells. Cerebellum (b) and rhombencephalic ventricle (d) in treated lizard: reduction of tinctorial affinity, diffuse oedemas (arrows) and cellular disorganization of the ependymal cells $(*)$. Scale bars: $30 \mu \mathrm{m}$.
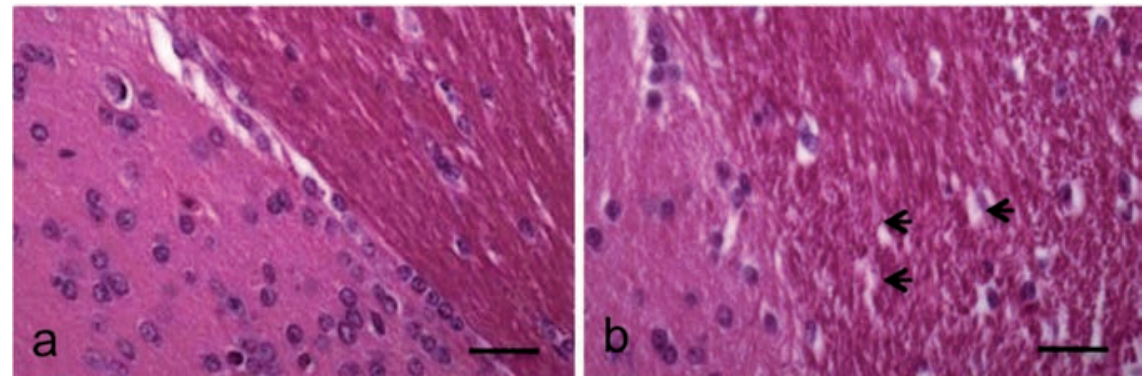

Figure 2. H\&E stain. Sections of $P$. siculus brain. a) Brain parenchyma of control lizard: normal general histology of the tissue. b) Brain parenchyma of treated lizard after 7 days from treatment: evident and diffuse oedemas (arrows). Scale bars: $30 \mu \mathrm{m}$. 
positive structures were observed in the optic tectum and in the medulla oblongata (Figure 3d) with a strong staining. Thin fibres GFAP-positive were present in the telencephalon parenchyma. The type of glial cells more revealed was radial glia (Figure 3 a-d). At 2 days from injection of cadmium the pattern of GFAP immunopositive structures were generally similar to those observed in control lizards (Figure $3 \mathrm{e}, \mathrm{h}$ ). In this group an evident decrease of immunoreactivity was revealed in the telencephalon at level of the radial fibres that are juxtaposed to meningeal surface (Figure 3f), an important structure for the homeostasis of the brain parenchyma and in the optic tectum (Figure $3 \mathrm{~g}$ ). In the latter the mean of percentage area values measured was $13.4 \pm 0.7 \%$ while after 2 days this value was significantly reduced to $9.4 \pm 1 \%(\mathrm{P}<0.01)$ (Figure 4). In the telencephalon after two days the immunostained percentage area changed significantly from $6.76 \pm 1.4 \%$ of control to $3 \pm 0.1 \%(\mathrm{P}<0.01)$ (Figure 4$)$. In this area a strong decrease of immunoreactivity was detected up to 16 days when in some sections we did not observe positivity to anti-GFAP antibody, with a mean percentage value of immunopositive area of $1.66 \pm 1 \%(\mathrm{P}<0.001)$ (Figures 3 and 4$)$. At 7 and 16 days from the injection the lizard brains showed also a sensible decrease of the GFAP-immunoreaction in the ventricular areas where the mean percentage value of immunopositive area changed from $3 \pm 1 \%$ of the control to $0.56 \pm 0.4 \%(\mathrm{P}<0.05)$ and $0.16 \pm 0.15 \%(\mathrm{P}<0.05)$, respectively and in the optic tectum where these values were $8.3 \pm 0.6 \% \quad(\mathrm{P}<0.001) \quad$ and $\quad 5.9 \pm 1.2 \%$ $(\mathrm{P}<0.001)$ (Figure 4). In particular this decrease was observed for the fibres running from rhombencephalic ventricle and those present in the meningeal layers of optic tectum (Figure $3 \mathrm{i}, \mathrm{m}$ ). These results show that in the lizards an acute exposure to cadmium provokes morphological cellular alterations in the brain but also a decrement of the expression of GFAP marker with possible consequent damage in the function of the glial cells.

\section{Discussion}

These results show the ability of $\mathrm{Cd}$ to damage the brain parenchyma of $P$. siculus. This metal was administered by a single intraperitoneal injection of $\mathrm{CdCl}_{2}$, a procedure that previously was used in the same species $^{28}$ and proved to determine a progressive bioaccumulation of $\mathrm{Cd}$ in the brain up to 16 days from the injection, ${ }^{19}$ to induce also apoptosis of the pituitary cells, ${ }^{18}$ and suggesting a possible direct long term effect of $\mathrm{Cd}$ on this organ. ${ }^{28}$ In lizard in fact this metal accumulates in kidney and ovary in the first days after a single injection, at 7 days it decreases in these organs and
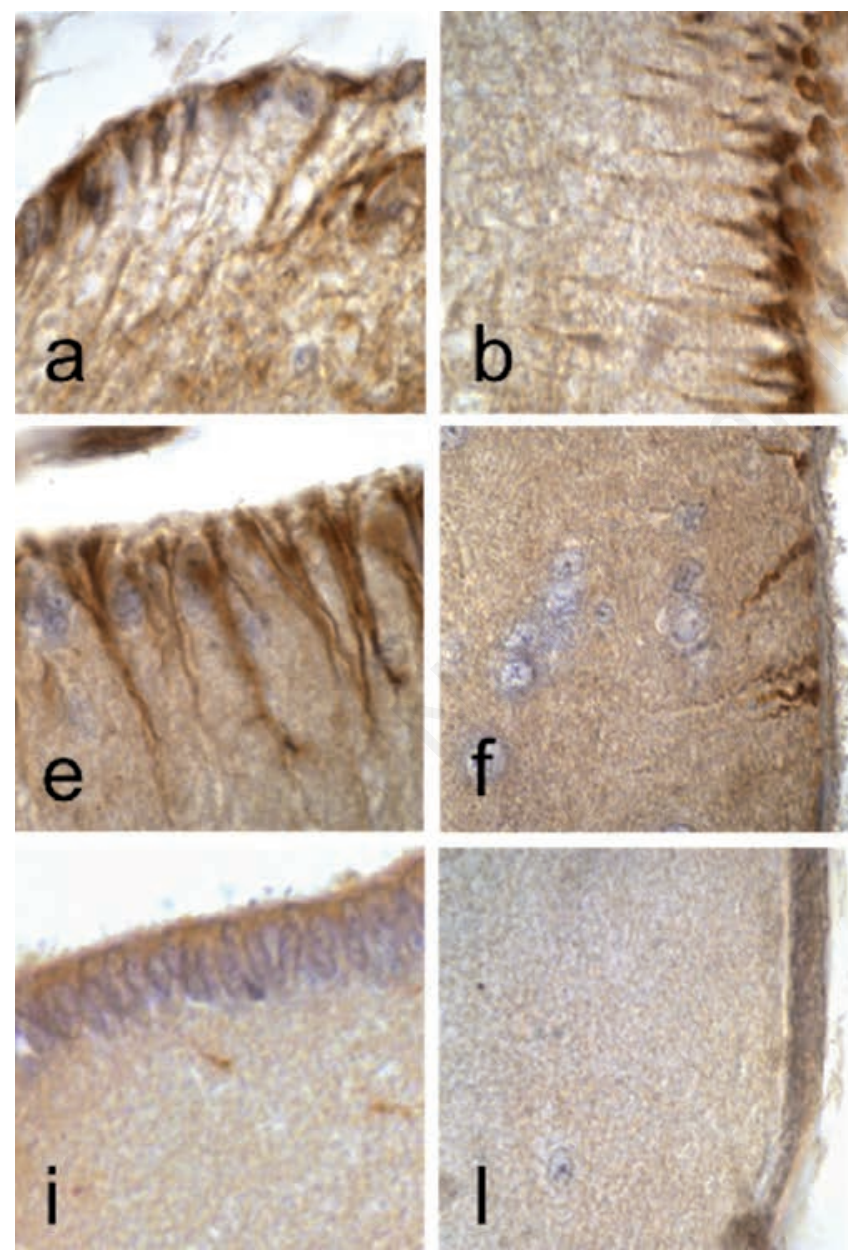
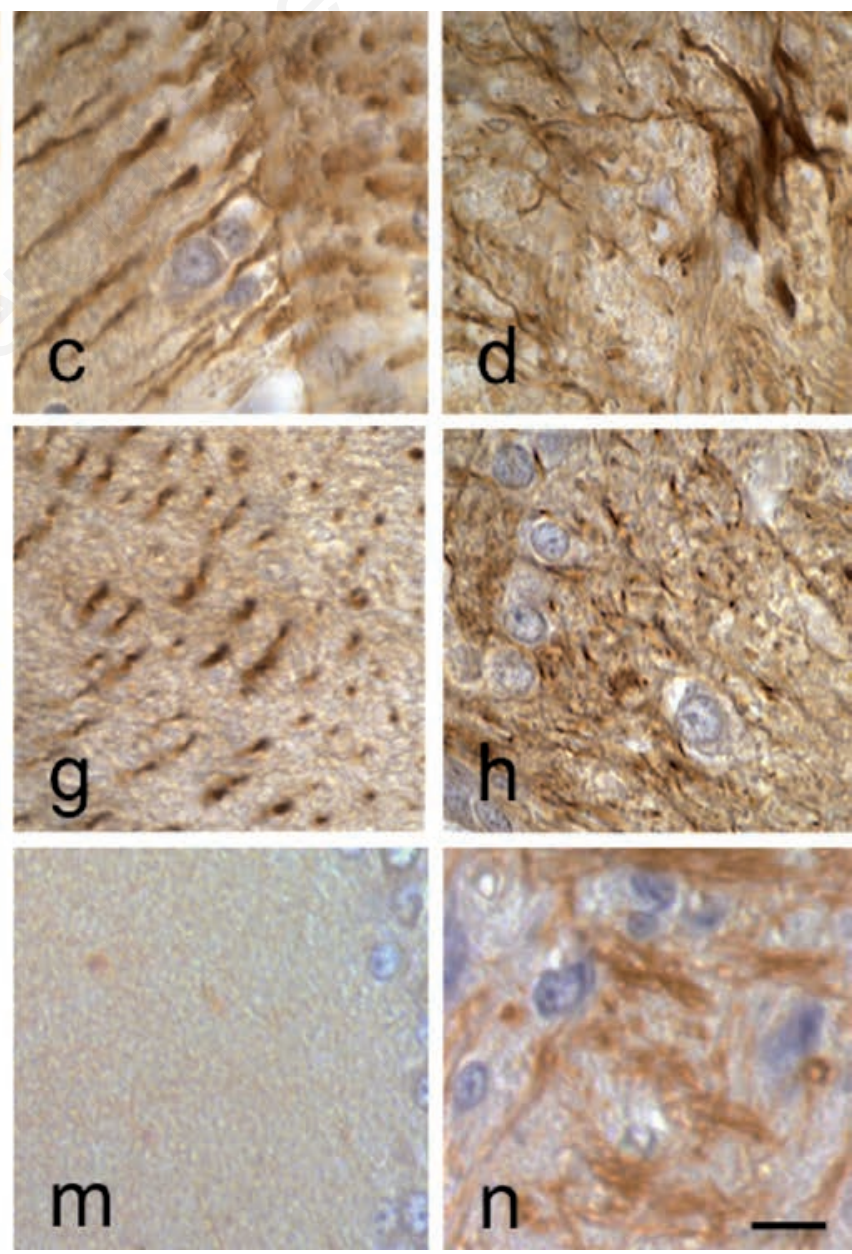

Figure 3. ABC technique. Immunodetection of GFAP. Sections of P.siculus brain. a) Rhombencephalic ventricle; b) telencephalon; c) optic tectum; d) medulla oblongata in control lizard. e) Rhombencephalic ventricle; f) telencephalon; g) optic tectum; h) medulla oblongata in lizard after 2 days from treatment: decrease of GFAP immunoreactivity in the telencephalic area respect the control group. i) Rhombencephalic ventricle; $n$ ) medulla oblongata in lizard at 7 days (l) telencephalon and (m) optic tectum in lizard at 16 days: strong reduction of the GFAP immunoreactivity also in the ventricle and in the optic tectum. Scale bars: $10 \mu \mathrm{m}$. 
increases gradually in liver but also in brain. ${ }^{28}$ The oedematous alterations that we have observed are probably caused by alteration of brains blood vessels and correlate to the damages on the integrity and functions of the BBB, the main cause of formation of oedemas. ${ }^{31}$ We can suppose that also in the present experimental procedure $\mathrm{Cd}$ was penetrated in the lizard brains by crossing the BBB and affected the organ. Cadmium is known to increase permeability of the $\mathrm{BBB},{ }^{32}$ penetrate and accumulate in the brain of developing and adult animals, leading to brain intracellular accumulation, cellular dysfunction, and cerebral oedema. ${ }^{33,34}$ In addition to tissue damage, $\mathrm{Cd}$ also increases the exposure of the brain to other potentially hazardous substances. ${ }^{32}$ The BBB is a neurovascular unit formed by endothelial cells, pericytes and astroglial endfeet. ${ }^{35}$ The blood-brain barrier of the central nervous system of the reptiles Anolis carolinensis $^{36}$ and Podarcis sicula ${ }^{37}$ is based on the presence of "tight" or occluding intercellular junctions between endothelial cells similiar to mammals. The effects of $\mathrm{Cd}$ on endothelial cells ${ }^{38,39}$ have been already reported as well as studies performed on glial cells..$^{40-42}$

Several in vivo studies have shown a range of possible effects of $\mathrm{Cd}$ on glial cells depending on dosage, time of exposure and experimental model used. ${ }^{43-45}$ In mammals, cadmium impairs GFAP expression in the astroglia; in fact Mori et al. ${ }^{43}$ observed a reduction of GFAP network after exposure to $\mathrm{CdCl}_{2}$ in mouse stem cell/progenitors and
Kovalchuk et al. ${ }^{45}$ showed a reduction of soluble GFAP in experiments performed in rats. In this work the presence of $\mathrm{Cd}$ into the lizard brain parenchyma is associated to a reduction of GFAP expression, a protein that is upregulated in many cases of cerebral damage, infection and diseases. ${ }^{46}$ In literature the process of reactive astrogliosis is well known and is characterized by overexpression of GFAP, hypertrophia and proliferation of astroglia with subsequent formation of glial scar. ${ }^{47}$ Indeed, in lizard we have revealed a decrease of GFAP expression. This evidence was also previously reported in the zebrafish brain, in which histological alterations, reduction of GFAP expression and bioaccumulation were observed after Cd exposure. ${ }^{44,48}$ Several studies of astroglial cells characterization made in the last years ${ }^{23-27,49-52}$ have shown that, differently to mammals, in reptiles and fish the principal type of astroglia is radial glia. This cell type could have evidently a particular susceptibility to $\mathrm{Cd}$, with a probable different reactivity to this metal compared to the astrocytes. The cause of GFAP reduction could be sought in the context of known oxidizing power of $\mathrm{Cd}^{53}$ Furthermore, because this metal have chemical similarity to zinc and calcium it can disrupt the metabolism of such elements. ${ }^{54}$ The perturbation of these homeostases could have deleterious effects since the calcium-dependent enzymes activities have a fundamental role in regulating the stability of the GFAP. ${ }^{55}$ In the last years it was discovered that the radial glia cells at ventricular level

\section{Reduction of GFAP expression}

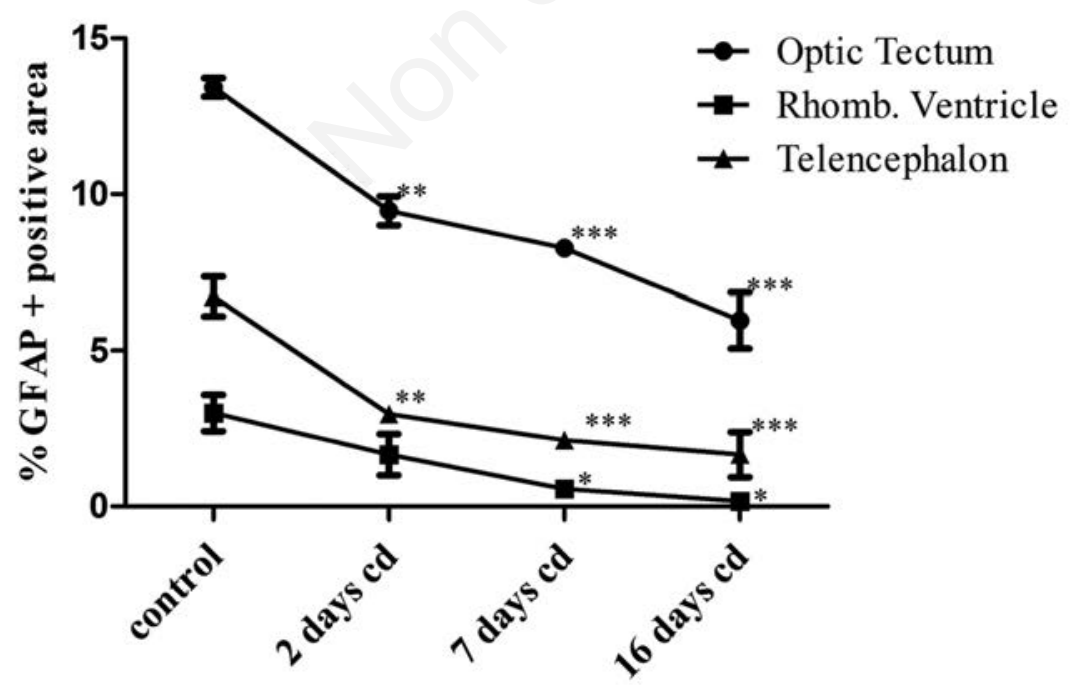

Figure 4. Graphical representation of the mean percentage values of GFAP immunopositive area for optic tectum, rhombencephalic ventricle, meningeal surface of telencephalon in Podarcis siculus encephalon. The values are significantly reduced for each encephalon part relative to the same part of control animals: ${ }^{*} \mathbf{P}<0.05$; ${ }^{* *} \mathrm{P}<0.01 ;{ }^{* * *} \mathrm{P}<0.001$.

are implicated also in the processes of adult neurogenesis and regeneration of nerve tissue in many species of vertebrates. ${ }^{56-58}$ Therefore, the decrease of GFAP expression could be related to the reduction of astroglial cells functionality, consequently affecting the nervous cells homeostasis and fundamental processes for the survival of these reptiles such as adult neurogenesis and the ability to regenerate damaged tissues. These results have a considerable ecological importance considering the significant contamination of $\mathrm{Cd}$ at level of aquatic and terrestrial ecosystems occurred in last years as a result of massive industrial activity and poor waste management. Considering the importance of brain glial cells in life and functions of animals ${ }^{59}$ and the importance of lizards in terrestrial ecosystems this work confirms and emphasizes the importance of environmental contamination by $\mathrm{Cd}$.

\section{References}

1. Dimou L, Götz M. Glial cells as progenitors and stem cells: new roles in the healthy and diseased brain. Physiol Rev 2014;94:709-37.

2. Bacci A, Verderio C, Pravettoni E, Matteoli M. The role of glial cells in synaptic function. Philos Trans R Soc Lond B Biol Sci 1999;354:403-9.

3. Terni B, López-Murcia FJ, Llobet A. Role of neuron-glia interactions in developmental synapse elimination. Brain Res Bull 2016; 16:30231-3.

4. Tiffany-Castiglioni E, Sierra EM, Wu JN, Rowles TK. Lead toxicity in neuroglia. Neurotoxicology 1989;10:41743.

5. Anderl JL, Redpath S, Ball AJ. A neuronal and astrocyte co-culture assay for high content analysis of neurotoxicity. J Vis Exp 2009;pii:1173.

6. Ayres RU. Toxic heavy metals: materials cycle optimization, PNAS 1992; 89:815-820.

7. Burger J, Gaines KF, Boring CS, Stephens WL, Snodgrass J, Dixon C, et al. Metal levels in fish from the Savannah River: potential hazards to fish and other receptors. Environ Res 2002;89:85-97.

8. Godt J, Scheidig F, Grosse-Siestrup C, Esche V, Brandenburg P, Reich A, et al. The toxicity of cadmium and resulting hazards for human health. J Occup Med Toxicol 2006; 10:1-22.

9. Cuypers A, Plusquin M, Remans T, Jozefczak M, Keunen E, Gielen H, et al. Cadmium stress: an oxidative chal- 
lenge. Biometals 2010;23:927-940.

10. Waisberg M, Joseph P, Hale B, Beyersmann D. Molecular and cellular mechanisms of cadmium carcinogenesis. Toxicology 2003;192: 95-117.

11. Sudo J, Hayashi T, Kimura S, Kakuno $\mathrm{K}$, Terui J, Takashima $\mathrm{K}$, et al. Mechanism of nephrotoxicity induced by repeated administration of cadmium chloride in rats. J Toxicol Environ Health 1996;48:333-48.

12. Okuda B, Iwamoto Y, Tachibana H, Sugita M. Parkinsonism after acute cadmium poisoning. Clin Neurol Neurosurg 1997;99:263-5.

13. Gerspacher C, Scheuber U, Schiera G, Proia P, Gygax D, Di Liegro I. The effect of cadmium on brain cells in culture. Int J Mol Med 2009; 24: 311-318.

14. Tiffany-Castiglioni E, Qian Y. Astroglia as metal depots: molecular mechanisms for metal accumulation, storage and release. NeuroToxicology 2001;22: 577-92.

15. Hossain S, Liu H.N, Nguyen M, Shore G, Almazan G. Cadmium exposure induces mitochondria-dependent apoptosis in Oligodendrocytes. NeuroToxicology 2009;30:544-54.

16. Rai A, Maurya SK, Khare P, Srivastava A, Bandyopadhyay S. Characterization of developmental neurotoxicity of As, $\mathrm{Cd}$, and $\mathrm{Pb}$ Mixture: synergistic action of metal mixture in glial and neuronal functions. Toxicol Sci 2010:118;586-601.

17. Campbell KR, Campbell TS, Burger J. Heavy metal concentrations in northern water snakes (Nerodia sipedon) from East Fork Poplar Creek and the Little River, East Tennessee, USA. Arch Environ Contam Toxicol 2005;49:239-48.

18. Ferrandino I, Favorito R, Annunziata M, Grimaldi MC. Cadmium induces apoptosis in the pituitary gland of Podarcis sicula. Ann N Y Acad Sci 2009;1163:386-8.

19. Favorito R, Grimaldi MC, Coppola M, Ferrandino I. Effects of acute cadmium exposure on the pituitary gland of Podarcis sicula. Open Zool J 2010;3: 30-6.

20. Ferrandino I, Viscardi G, Grimaldi MC. An immunohistochemical study of adenohypophysial cells in the viviparous reptile Chalcides chalcides. Histochem J 2001;33:1-8.

21. Ferrandino I, Favorito R, Grimaldi MC. Cadmium induces changes on $\mathrm{ACTH}$ and PRL cells in the Podarcis sicula lizard pituitary gland. Europ J Histochem 2010;54:e45.

22. Dahl D, Bignami A. Intermediate filaments in nervous tissue. In: J.W. Shay (ed.) Cell muscle mMotility. 6. Plenum Press New York, 1985; pp. 75-96.

23. Kálmán M, Pritz MB. Glial fibrillary acidic protein-immunopositive structures in the brain of a Crocodilian, Caiman crocodilus, and its bearing on the evolution of astroglia. J Comp Neurol 2001;431:460-80.

24. Lazzari M, Franceschini V. Glial fibrillary acidic protein and vimentin immunoreactivity of astroglial cells in the central nervous system of adult Podarcis sicula (Squamata, Lacertidae). J Anat 2001;198:67-75.

25. Ahboucha S, Laalaoui A, Didier-Bazes M, Montange M, Cooper HM, Gamrani H. Differential patterns of glial fibrillary acidic protein-i mmunolabeling in the brain of adult lizards. J Comp Neurol 2003;464: 159-71.

26. Lazzari M, Franceschini V. Astroglial cells in the central nervous system of the adult brown anole lizard, Anolis sagrei, revealed by intermediate filament immunohistochemistry. J Morphol 2005;265:325-34.

27. Lazzari M, Franceschini V. Glial cytoarchitecture in the central nervous system of the soft-shell turtle, Trionyx sinensis, revealed by intermediate filament immunohistochemistry. Anat Embryol 2006;211:497-506.

28. Trinchella F, Riggio M, Filosa S, Volpe MG, Parisi E, Scudiero R. Cadmium distribution and metallothionein expression in lizard tissues following acute and chronic cadmium intoxication. Comp Biochem Physiol C Toxicol Pharmacol 2006;144:272-8.

29. Ferreira T, Rasband W. Quantifying stained liver tissue. In: ImageJ User Guide, 2012. Research Service Branch, National Institutes of Heath, Bethesda, MD, USA.

30. Chan SY, Hancox LA, Martin-Santos A, Loubiere LS, Walter MN, Gonzalez $\mathrm{AM}$, et al. MCT8 expression in human fetal cerebral cortex is reduced in severe intrauterine growth restriction. J Endocrinol 2014; 2:85-95.

31. Scorticati C, Prestifilippo JP, Eizayaga FX, Castro JL, Romay S, Fernández MA, et al. Hyperammonemia, brain oedema and blood-brain barrier alterations in prehepatic portal hypertensive rats and paracetamol intoxication. World J Gastroenterol 2004;10:1321-4.

32. Shukla GS, Chandra SV. Concurrent exposure to lead, manganese, and cadmium and their distribution to various brain regions, liver, kidney, and testis of growing rats. Arch Environ Con Tox 1987;16:303-10.
33. Goncalves JF, Fiorenza AM, Spanevello RM, Mazzanti CM, Bochi GV, Antes $\mathrm{FG}$, et al. $\mathrm{N}$-acetylcysteine prevents memory deficits, the decrease in acetylcholinesterase activity and oxidative stress in rats exposed to cadmium. Chem-Biol Interact 2010; 186:53-60.

34. Mendez-Armenta M, Rios C. Cadmium neurotoxicity. Environl Toxicol Phar 2007;23:350-8.

35. Ballabh P, Braun A, Nedergaard M. The blood-brain barrier: an overview: structure, regulation, and clinical implications. Neurobiol Dis 2004;16:1-13.

36. Shivers RS. The blood-brain barrier of a reptile, Anolis carolinensis. A freeze-fracture study. Brain Res 1979;169:221-30.

37. Lazzari M, Franceschini V. Structural and spatial organisation of brain parenchymal vessels in the lizard, Podarcis sicula: a light, transmission and scanning electron microscopy study. J Anat 2000;197:167-75.

38. Kolluru GK, Tamilarasan KP, Geetha Priya S, Durgha NP, Chatterjee S. Cadmium induced endothelial dysfunction: consequence of defective migratory pattern of endothelial cells in association with poor nitric oxide availability under cadmium challenge. Cell Biol Int 2006;30:427-38.

39. Jeong EM, Moon CH, Kim CS, Lee SH, Baik EJ, Moon CK, et al. Cadmium stimulates the expression of ICAM-1 via NF-kappaB activation in cerebrovascular endothelial cells. Biochem Biophys Res Commun 2004;320:887-92.

40. Hossain S, Liu HN, Nguyen M, Shore G, Almazan G. Cadmium exposure induces mitochondria-dependent apoptosis in oligodendrocytes. Neurotoxicology 2009;30:544-54.

41. Im JY, Paik SG, Han PL. Cadmiuminduced astroglial death proceeds via glutathione depletion. J Neurosci Res 2006;83:301-8.

42. Choi MK, Kim BH, Chung YY, Han MS. Cadmium-induced apoptosis in h9c2, a7r5, and c6-glial cell. Bull Environ Contam Toxicol 2002;69:33541.

43. Mori H, Sasaki G, Nishikawa M, Hara M. Effects of subcytotoxic cadmium on morphology of glial fibrillary acidic protein network in astrocytes derived from murine neural stem/progenitor cells. Environ Toxicol Pharmacol 2015;40:639-44.

44. Monaco A, Grimaldi MC, Ferrandino I. Neuroglial alterations in the zebrafish brain exposed to cadmium chloride. J Appl Toxicol 2016;36:1629-38. 
45. Kovalchuk YP, Prischepa IV, Si U, Nedzvetsky VS, Kot YG, Persky EE, et al. Distribution of glial fibrillary acidic protein in different parts of the rat brain under cadmium exposure. Ukr Biochem J 2015;87:116-23.

46. Pekny M, Nilsson M. Astrocyte activation and reactive gliosis. Glia 2005;50:427-34.

47. Sofroniew MV. Molecular dissection of reactive astrogliosis and glial scar formation. Trends Neurosci 2009;32:638-47.

48. Favorito R, Chiarelli G, Grimaldi MC, De Bonis S, Lancieri M, Ferrandino I. Bioaccumulation of cadmium and its cytotoxic effect on zebrafish brain. Chem Ecol 2011;27(Suppl.2):39-46.

49. Ferrandino I, Grimaldi MC. Ultrastructural study of the pituicytes in the pituitary gland of the teleost Diplodus sargus. Brain Res Bull 2008; 75:133-7.
50. Grupp L, Wolburg H, Mack AF. Astroglial structures in the zebrafish brain. J Comp Neurol 2010;518: 4277-87.

51. Kálmán M. Astroglial architecture of the carp (Cyprinus carpio) brain as revealed by immunohistochemical staining against glial fibrillary acidic protein (GFAP). Anat Embryol 1998; 198:409-33.

52. Cuoghi B, Mola L. Macroglial cells of the teleost central nervous system: a survey of the main types. Cell Tissue Res 2009;338:319-32.

53. Cuypers A, Plusquin M, Remans T, Jozefczak M, Keunen E, Gielen H, et al. Cadmium stress: an oxidative challenge. Biometals 2010;23:927-40.

54. Jiang JH, Ge G, Gao K, Pang Y, Chai $\mathrm{RC}$, Jia $\mathrm{XH}$, et al. Calcium signaling involvement in cadmium-induced astrocyte cytotoxicity and cell death through activation of MAPK and PI3K/Akt signaling pathways. Neurochem Res
2015;40:1929-44.

55. Heimfarth L, Loureiro SO, Dutra MF, Petenuzzo L, de Lima BO, Fernandes $\mathrm{CG}$, et al. Disrupted cytoskeletal homeostasis, astrogliosis and apoptotic cell death in the cerebellum of preweaning rats injected with diphenyl ditelluride. Neurotoxicology 2013;34:175-88.

56. Alunni A, Bally-Cuif L. A comparative view of regenerative neurogenesis in vertebrates. Development 2016;143: 741-53.

57. Pellegrini E, Diotel N, VaillantCapitaine C, Pérez Maria R, Gueguen MM, Nasri A, et al. Steroid modulation of neurogenesis: focus on radial glial cells in zebrafish. J Steroid Biochem Mol Biol 2016;160:27-36.

58. Kempermann G. Adult neurogenesis: an evolutionary perspective. Cold Spring Harb Perspect Biol 2015;8:a018986.

59. Jessen KR. Glial cells. Int J Biochem Cell Biol 2004;36:1861-7. 